\title{
FDI Flows to Latin America: A Pooled and Cointegration Analysis, 1980-2014
}

\author{
Miguel D. Ramirez \\ Professor of Economics in the Department of Economics \\ Trinity College, Hartford, CT, USA \\ E-mail: Miguel.Ramirez@trincoll.edu
}

Received: June 13, 2017 Accepted: July 8, 2017

doi:10.5296/ber.v7i2.11682ＵRL: https://doi.org/10.5296/ber.v7i2.11682

\begin{abstract}
This paper estimates a pooled (fixed-effects) FDI investment function that seeks to identify some of the major economic and institutional determinants of net FDI flows to nine major Latin American countries during the 1980-2014 period. First, it develops a conceptual framework of analysis that seeks to identify some of the major economic and institutional determinants of FDI. Second, the paper gives an overview of FDI flows to Latin America during the 1990-2015 period, with particular emphasis on their contribution to the financing of gross capital formation. Third, an empirical model for FDI flows to Latin America is outlined and an economic rationale is provided for the included variables and their expected signs. Fourth, the estimates from a panel regression designed to explain the variation in FDI flows to Latin America during the 1980-2014 period suggests that market size (proxied by real GDP), credit provided by the private banking sector, government expenditures on education, and the level of economic freedom as measured by the Fraser Institute have a positive and significant effect. On the other hand, public investment spending, the volatility of real GDP and the real exchange rate have a negative and significant effect on FDI flows. The panel unit root tests on the residuals of the relevant panel regressions also suggest that there is a stable, long-term relationship among the included variables; i.e., the selected variables in the reported regressions are cointegrated over the relevant time period. Finally, the paper summarizes the major findings and offers some policy prescriptions for attracting FDI flows to the region and enhancing their positive direct and indirect effects.
\end{abstract}

Keywords: Economic Freedom Index (EFI), Foreign Direct Investment (FDI), Latin America, Pedroni Residual Cointegration Test, Pooled Regression, Remittances of FDI profits, and Seemingly Unrelated Regression (SUR)

JEL Classifications: C22, C23, F40, FO10, O50 


\section{Introduction}

The demise of import substitution industrialization (ISI) in most of the countries of Latin America and the Caribbean during the 1980s and 1990s led to the adoption and consolidation of a market-based, outward-oriented strategy of economic growth and development. Along with the wholesale privatization of state-owned industries and the deregulation of financial and labor markets, this market-based strategy has been associated with a dramatic liberalization of trade and the opening of capital markets. Insofar as capital flows are concerned, foreign direct investment (FDI) under the auspices of transnational corporations has become one of the key elements in the process of economic and financial integration of the region. The importance of these flows to the region can be surmised from the following figures: net FDI flows to the countries of Latin America and the Caribbean rose dramatically from $\$ 8.4$ billion in 1990 to $\$ 77.2$ billion in 2000 and almost 100 billion in 2008, before falling precipitously to 72.2 billion during the recessionary years of 2009 and 2010 (see UNCTAD, 2015). However, in the wake of the dramatic economic recovery experienced by South America (particularly, Argentina, Brazil, Chile, and Peru) during the 2010-12 period, these net flows are estimated to have risen sharply to 153.5 billion in 2011 (see UNCTAD, 2015; and ECLAC, 2016). From a relative standpoint, Latin America's share of FDI flows to developing countries rose from 29 percent in 1995 to an-all time high of 39.5 percent in 2000, before falling to 28.9 percent during the recession year of 2009, and then rebounding, respectively, to 30.5 and 32 percent in 2010 and 2011-12. The region's share fell again to 25.3 percent in 2013-14 following a significant decline in cross-border mergers and acquisitions in Central America and lower commodity prices which reduced investment in extractive industries, particularly in South America (see UNCTAD, 2015, pp. 58-62). As discussed below, another reason for the fall in the share of FDI flows to the region in recent years can be explained by the completion of major privatizations in industry, banking, and mining in the region (see UNCTAD, 2012). The recent resurgence in FDI inflows to the region was led primarily by investments in natural resource endowments (copper, nickel, and oil), mergers and acquisitions, and greenfield investments in manufacturing and services in Brazil, Chile and Mexico, and it remains to be seen whether it can be sustained beyond the immediate future (see UNCTAD 2015, pp. 58-64).

The economic rationale for opening the region's capital markets to both portfolio and FDI flows resides in the belief that foreign capital can help bridge the gap between savings and investment in capital-scarce economies and, particularly in the case of FDI flows, bring modern technology and managerial knowhow that promotes economic growth and encourages the development of financial markets. There is also a growing body of empirical evidence which suggests that FDI flows, as opposed to portfolio investments in the form of short-term bond and equity investments, are less volatile because they involve longer term commitments that often lead to the establishment of foreign subsidiaries as well as the acquisition of existing entities via international mergers (see Bird and Rajan, 2001; Bosworth and Collins, 1999; Kumar, 2007; Montecinos and Cordero, 2010; and Prasan and Rajan, 2008). FDI is often referred to as the "good cholesterol" because, from a macroeconomic standpoint, it is less likely than portfolio investments to leave emerging markets at the first 
hint of economic trouble as evidenced by their relative stability and growth during the financial and economic crises that have buffeted emerging markets during the 1990s and beyond (see Kumar, 2007, Chart 2; Bird and Rajan, 2001, Tables 3 and 5; and Prasan and Rajan, 2008). Finally, to the degree that FDI flows are directed to the establishment of new enterprises in leading sectors, such as greenfield investments, as opposed to the buying of existing firms via mergers and acquisitions, or brownfield investments, the economic impact of these flows on long-term regional growth and development is likely to be greater (see Zhuang, 2012; and Wang and Wong, 2009).

In view of importance of this topic for the future economic performance of Latin America, this paper estimates a pooled (fixed-effects) FDI investment function that seeks to identify some of the major economic and institutional determinants of FDI flows to nine major Latin American countries during the 1980-2014 period. The paper is organized as follows: First, the paper develops a conceptual framework of analysis that seeks to identify some of the major economic and institutional determinants of FDI. Second, the paper gives an overview of FDI flows to Latin America during the more recent 1990-2015 period, with particular emphasis on their contribution to the financing of gross capital formation. Third, an empirical model for FDI flows to Latin America is outlined and an economic rationale is provided for the included variables and their expected signs. Fourth, the paper reports estimates from a panel regression designed to explain the variation in FDI flows to Latin America during the 1980-2014 period - it could not be extended to 2015 because of a lack of data for key variables. It also undertakes panel unit root tests on the residuals of the relevant panel regressions to determine whether there is a stable, long-term relationship among the included variables; i.e., it tests whether the selected variables in the reported regressions are cointegrated. Finally, the paper summarizes the major findings and offers some policy prescriptions for attracting FDI flows to the region and enhancing their positive direct and indirect effects.

\section{Conceptual Framework}

Following the lead of Ronald Coase, John Dunning $(1981 ; 1988)$ has articulated one of the most comprehensive explanations of why TNC firms undertake cross-border investments. He argues that TNCs invest abroad when three sets of relative advantages are present. First, the establishment of TNC subsidiaries gives the parent firms exclusive ownership rights over patents, trademarks, commercial secrets and production processes, thereby effectively denying access to both foreign and domestic competitors. Second, they generate for TNC affiliates locational advantages that arise from direct access to growing markets and lower unit labor costs, reduced transportation and communication costs, avoidance of tariffs and non-tariff barriers, and last but not least, direct access to raw materials, low-cost unskilled labor, and intermediate products that are indispensable for the production of certain goods. Michael Mortimore (2003), building on Dunning's work, argues that the relative importance of location specific determinants depends on TNC motivations for investing, viz., whether FDI is motivated by market-seeking (access to internal and export markets), natural resource-seeking (access to natural resources and low-cost labor) or efficiency-seeking reasons (cost and quality of human resources and physical infrastructure resources). 


\section{Mll Macrothink}

Business and Economic Research

ISSN 2162-4860

2017, Vol. 7, No. 2

Third, Dunning highlights the advantages TNCs derive from internalizing certain operations because utilizing market mechanisms are relatively more burdensome and costly. For instance, many TNCs would rather establish a subsidiary abroad and assume directly the contractual and administrative costs associated with research, development, production, and marketing of a given product or service, thereby avoiding the transaction costs associated with leasing licenses and securing patents to undertake production or hiring the services of advertising agencies to market and distribute their products. In this connection, Spitaler (1971) and Markusen (1995) argue that firms choose direct investment rather than licensing primarily because of the non-excludability property of new knowledge capital; viz., it is too costly for TNCs to prevent licensees from "defecting" and copying the new technology at little cost and setting up their own domestic firms in direct competition with the TNCs.

Thus, a fourth and highly important determinant of FDI not entirely emphasized by Dunning is based on strategic considerations. The decision by TNCs to undertake investments abroad for strategic reasons has been greatly facilitated in recent years by the globalization of financial markets which, in turn, has significantly reduced entry barriers associated with large fixed costs. For example, Aliber (1970) and others contend that large TNCs, with their greater (and cheaper) access to financial capital, have both the ability and the incentive to enter foreign markets to preserve market share and profits which are threatened by other indigenous and foreign firms. For similar strategic and tax reasons, TNCs are able to give the appearance of repatriating a lower profit without reducing their actual profit by manipulating intra-firm transfer pricing. For example, TNCs have the incentive to charge high prices for inputs to subsidiaries operating in high-tax countries and charge low prices for the output which these subsidiaries sell back to the parent company. In this manner the TNC is able to attain a number of strategic objectives, viz., it is able to keep its reported profit rate low and thus reduce its overall corporate taxes; it is also likely to avoid bad publicity and potential expropriation via accusations of price gouging from the host country government; and last but not least, it is able to discourage the entry of indigenous firms and foreign firms who perceive incorrectly the profit opportunities available in the market (see Cypher and Dietz, 2004; and Levi 2005) .

Fifth, host country determinants also seem to play a very important role in either attracting or discouraging FDI flows to developing countries. For example, countries that exhibit a greater degree of political and macroeconomic stability, the existence of well-defined and enforceable property rights when it comes to the transfer of technology, liberal legislation governing the remittance of profits and dividends, and limited or non-existent local content or export requirements tend, on average, to attract greater flows of FDI. However, from the standpoint of the host country the very factors which act as an incentive for FDI flows in the short run may prove detrimental to long-term economic development if they lead to a net outflow of resources, few backward and forward linkages (an "enclave" facility), the elimination of domestic firms that could have developed into successful enterprises without this premature exposure to competition, and limited transfers of technology and managerial knowhow [see Chang, 2008; ECLAC, 1998, pp. 89-91; Montecinos and Cordero, 2010; Ram and Zhang, 2002; and Yeager, 1999]. 


\section{Mll Macrothink}

Business and Economic Research

ISSN 2162-4860

2017, Vol. 7, No. 2

The nature and scope of government policies are also a highly important factor in determining whether FDI flows to developing economies such as Chile. For example, FDI is likely to be attracted to countries where governments ensure an adequate provision of economic and social infrastructure in the form of paved roads, ports, airfields, relatively cheap energy supplies, and a well-educated and disciplined work force. In this connection, several investigators have found that the availability of skilled workers and adequate physical infrastructure are important determinants of FDI flows because it enables TNCs to strengthen both their ownership and locational advantages, thus allowing them to expand their market not only in the host country but the region as well (see Ramasamy and Young, 2004; and Zhao and Zhu, 2000). In addition, FDI flows are likely to be encouraged by government policies that lead to the establishment of a legal-institutional framework that is conducive to business activity; viz., one that significantly reduces the transactions costs associated with negotiating contracts, improves information about the quality of goods and services, and make sure that the parties to a formal agreement honor their commitments (see North, 1990; and Yeager, 1999).

Finally, changes in a country's exchange rate policy play a key role in altering its relative attractiveness to net FDI inflows. Not surprisingly, economists are not entirely of one mind when it comes to the optimal exchange rate strategy to pursue. For example, some investigators argue that a policy that keeps the real exchange rate undervalued relative to that of its key investment partners is, ceteris paribus, likely to enhance FDI flows because it artificially reduces the unit costs of the country's factors of production and thus enables investors to make a significantly larger investment in terms of the domestic currency. They also contend that it enhances the profitability of the export-oriented sector which, in turn, attracts FDI flows to them. Therefore, the amount of FDI should increase with a real devaluation of the domestic currency after a reasonable lag (see ECLAC, 1998).

Other researchers contend that a policy that leads to a real appreciation of the domestic currency is likely to encourage FDI inflows because it enhances the foreign currency (dollar) value of the remittances of profits and dividends back to the parent company (see De Mello, Jr., 1997). After all, it is the real rate of return on their initial (dollar) investment that matters to the parent company. In light of the conflicting views in the literature on the impact of the exchange rate on FDI flows, it is best, from a policy standpoint, to pursue a credible strategy that maintains the country's real exchange rate in line with that of its key trading and investment partners.

\section{FDI Flows to Latin America during the 1990-2015 Period}

Following the debt crisis, net FDI inflows (gross inflows minus outflows) to Latin America and the Caribbean declined in absolute terms during the first half of the 1980s, after which they began to increase steadily during the second half of the 1980s and posted a dramatic surge during the decade of the 1990s. For example, between 1985 and 1990 these flows averaged $\$ 8$ billion on an annual basis, while during the 1991-1999 period alone they averaged $\$ 55.8$ billion, or almost seven times as much (see ECLAC, 2006). The acceleration in FDI flows during the 1990s was also characterized by an increasing proportion of these 
funds directed to emerging nations such as China, India, as well as the major countries of Latin America and the Caribbean. For example, net FDI flows to Argentina, Chile, Brazil , Mexico, and Peru averaged close to $\$ 52$ billion during the 1996-2001 period, before falling to $\$ 37$ billion in 2002 , and $\$ 25.7$ billion in 2003 as a result of the relatively mild 2001 U.S. recession. Figure 1 below shows that with the recovery of economic activity in the United States after 2003, FDI flows to the countries of Latin American and the Caribbean resumed at a brisk pace as attested by the rise in net inflows to $\$ 57$ billion in $2005, \$ 96$ billion in 2007 , and slightly over $\$ 100$ billion in 2008 , before falling sharply in 2009 to $\$ 72.2$ billion in the aftermath of the Great Recession of 2007-09 (ECLAC 2016, Table A1-10, p. 97; and UNCTAD, 2015).

Figure 1 below also reveals that the abrupt fall in net FDI flows to Latin America and the Caribbean in 2009 was quickly reversed in 2010 when the region, led by Argentina, Brazil, Chile, Mexico, Peru, and Uruguay, experienced a sharp inflow of funds thanks, in part, to rising commodity prices and aggressive Keynesian-style countercyclical policies in countries such as China, India, Argentina, Brazil, Chile, and Ecuador--relative to their developed counterparts in Europe and the United States. According to ECLAC (2016), the surge in net inflows to the region that began in 2010 continued into 2011--attaining in that year an all-time high of $\$ 153.5$ billion--and thereafter ranging between $\$ 142$ to $\$ 148$ billion for the 2012 and 2014 period, before falling sharply in 2015 to $\$ 134$ billion. The rapid rise in FDI inflows that began in 2010 can be traced to a sharp improvement in the region's terms of trade resulting from relatively higher prices for key primary commodities such as copper, nickel, and petroleum induced by the strong demand for commodities by China and the United States; robust internal demand in the form of consumption and investment spending (particularly in Brazil, Chile Colombia and Ecuador); and last but not least, the high rate of return on capital investments in the region (see UNCTAD, 2012, p 53). The sharp fall in FDI inflows to Latin America and the Caribbean in 2015 and 2016 can be traced to a combination of external and internal factors, such as the deceleration of growth and investment in the region induced by the falling demand for commodities by China and the European Union, a 72 percent decrease in cross-border mergers and acquisitions in Central America and the Caribbean, and the exhaustion of countercyclical (populist) policies in countries such as Argentina, Brazil and Venezuela.

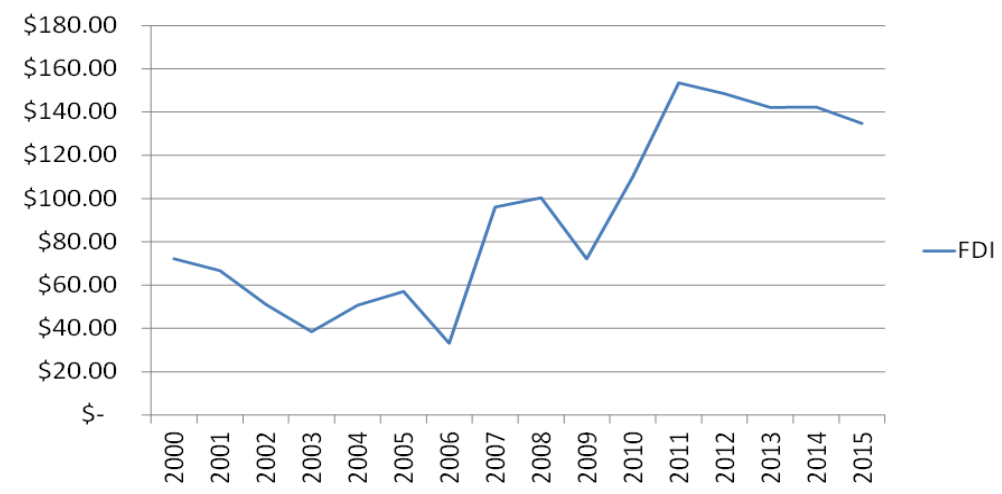

Figure 1. Net FDI Flows to Latin America, 2000-2015 (Billions of dollars)

Source: ECLAC, 2016; and UNCTAD, 2015 
More importantly, from the standpoint of economic growth and development, the increase in FDI inflows has been driven by robust investments in Greenfield investments in manufacturing and services, particularly in South America (Brazil and Chile) and Mexico - in the latter it is primarily directed to the auto parts and assembly sector and manufacturing in general. According to UNCTAD (2012), gross investments in new enterprises in leading sectors of Latin America

The importance of these net inflows is better appreciated by focusing on their recent evolution relative to GDP and the gross fixed capital formation of the major countries of the region, given FDI's important role in financing private capital formation. Figure 2 below show that net FDI inflows as a proportion of the region's GDP were quite significant during the 2000-2015 period. For example, with the exception of the years 2006 and 2009, these net flows have represented at least 2 percent of the region's GDP, and during 2010-15 they averaged an impressive 2.7 percent (with some years at or close to 3 percent of regional GDP).

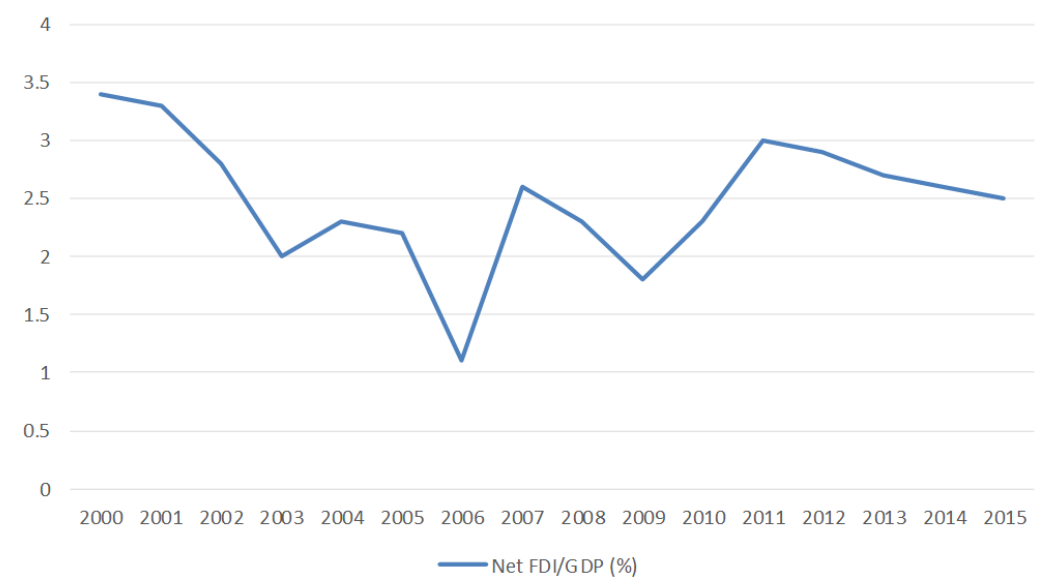

Figure 2. Net FDI Flows as a Percentage of Latin America's Gross Domestic Product

Source: ECLAC, 2016.

Table 1 below reports net FDI flows as a percentage of gross fixed capital formation during the decades of the 2000s; it reveals that, beginning in 2003, FDI inflows to the major countries of Latin America represented a significant percentage of their gross fixed capital formation; and in the cases of Colombia, Costa Rica, Chile, Ecuador, Peru, and Uruguay these flows reached at least one fifth of their gross fixed capital formation during the 2003-2012 period. For Latin America as a whole, net FDI inflows as a proportion of gross capital formation rose impressively from an average of only 8.5 percent during the 1987-97 period to a high of 20.7 percent in 2000, before falling somewhat to 15.4 percent in 2002 (see Table 1). Clearly, during the early 2000s, Latin America exhibited an impressive record of attracting FDI flows to finance gross fixed capital formation (see UNCTAD, 2012; and ECLAC, 2012). Notable performers during this period are Argentina, Chile, Costa Rica, Ecuador, Mexico, Uruguay, and Venezuela. However, as noted above, following the relatively mild U.S. recession of 2001 and the serious economic crisis in Argentina in 2001-2002, FDI inflows as a percentage of gross fixed capital formation fell sharply to a decennial low of 13 
percent in 2003. However, Table 1 shows that after 2003 the share of FDI inflows rebounded sharply to almost 24 percent in 2008, and despite the aftermath of the Great Recession of 2007-09, they proved to be resilient and fell only to approximately 18 percent in 2009-10. Still, in recent years, Table 1 shows that there has been a significant fall in the share of net FDI inflows in gross fixed capital formation due to the deceleration of growth and investment in the region alluded to above. In some notable cases, such as Mexico and Venezuela, foreign direct investment has diverted resources away from the financing of gross fixed capital formation - even before deducting profits and dividends (see the years 2012 and 2014 for Mexico and Venezuela, respectively).

Table 1. Selected Latin American Nations: Net Foreign Direct Investment Flows ${ }^{\text {a }}$ as a Percentage of Gross Fixed Capital Formation, 1997-2014

\begin{tabular}{|lrrrrrrrrrrrrrrrr|r|}
\hline Country & $\mathbf{1 9 9 7}$ & $\mathbf{2 0 0 0}$ & $\mathbf{2 0 0 1}$ & $\mathbf{2 0 0 2}$ & $\mathbf{2 0 0 3}$ & $\mathbf{2 0 0 4}$ & $\mathbf{2 0 0 5}$ & $\mathbf{2 0 0 6}$ & $\mathbf{2 0 0 7}$ & $\mathbf{2 0 0 8}$ & $\mathbf{2 0 0 9}$ & $\mathbf{2 0 1 0}$ & $\mathbf{2 0 1 1}$ & $\mathbf{2 0 1 2}$ & $\mathbf{2 0 1 3}$ & $\mathbf{2 0 1 4}$ \\
\hline Argentina & 2.7 & 25.3 & 8.4 & 17.6 & 9.6 & 15.0 & 11.0 & 11.1 & 10.1 & 11.8 & 9.8 & 16.9 & 13.0 & 21.2 & 12.9 & 4.9 \\
\hline Brazil & 11.9 & 28.4 & 22.7 & 19.6 & 11.3 & 16.0 & 9.0 & 10.3 & 14.0 & 13.9 & 18.9 & 14.1 & 18.1 & 17.2 & 10.8 & 14.9 \\
\hline Chile & 27.9 & 22.9 & 31.4 & 17.8 & 28.2 & 39.2 & 18.3 & 24.3 & 33.0 & 35.6 & 34.1 & 31.0 & 19.3 & 12.3 & 12.7 & 17.6 \\
\hline Colombia & 38.2 & 21.1 & 21.8 & 17.6 & 16.1 & 17.1 & 18.0 & 18.8 & 18.7 & 17.6 & 12.2 & 10.0 & 8.3 & 19.9 & 10.2 & 13.5 \\
\hline Costa Rica & 26.0 & 14.4 & 15.3 & 20.7 & 17.2 & 22.9 & 18.3 & 32.5 & 33.8 & 30.3 & 22.7 & 20.7 & 29.9 & 21.8 & 29.4 & 30.4 \\
\hline Ecuador & 18.5 & 32.7 & 45.2 & 23.0 & 25.1 & 16.5 & 6.0 & 3.3 & 1.9 & 8.1 & 2.8 & 4.0 & 3.9 & 3.2 & 3.7 & 3.5 \\
\hline Mexico & 16.3 & 13.7 & 20.7 & 12.1 & 9.4 & 16.7 & 8.0 & 10.0 & 13.9 & 11.0 & 8.8 & 9.3 & 5.0 & -0.9 & 14.1 & 8.1 \\
\hline Peru & 11.1 & 6.8 & 11.6 & 21.6 & 12.3 & 12.8 & 18.3 & 18.6 & 22.3 & 19.5 & 25.9 & 18.1 & 18.5 & 25.4 & 18.6 & 16.2 \\
\hline Uruguay & 5.3 & 10.3 & 14.0 & 15.6 & 39.4 & 22.3 & 39.0 & 41.1 & 29.9 & 32.6 & 25.4 & 28.9 & 30.5 & 26.2 & 30.0 & 20.8 \\
\hline Venezuela & 34.4 & 25.9 & 16.7 & 3.8 & 20.4 & 7.7 & 5.0 & 2.1 & 2.6 & 1.5 & 1.3 & 2.1 & 13.1 & 2.9 & 3.7 & -1.6 \\
\hline $\begin{array}{l}\text { Latin } \\
\text { America }\end{array}$ & $\mathbf{1 6 . 1}$ & $\mathbf{2 0 . 7}$ & $\mathbf{2 0 . 0}$ & $\mathbf{1 5 . 4}$ & $\mathbf{1 3 . 0}$ & $\mathbf{2 4 . 1}$ & $\mathbf{1 5 . 1}$ & $\mathbf{1 5 . 6}$ & $\mathbf{2 0 . 8}$ & $\mathbf{2 3 . 5}$ & $\mathbf{1 8 . 9}$ & $\mathbf{1 7 . 6}$ & $\mathbf{1 4 . 4}$ & $\mathbf{1 3 . 4}$ & $\mathbf{1 2 . 5}$ & $\mathbf{1 2 . 7}$ \\
\hline
\end{tabular}

Source: Computed by author from UNCTAD, World Investment Report, 1999, Tables B.1. and B.5., pp. 478 and 505-507; UNCTAD, World Investment Report, 2012, Annex Table I.1, p.171; ECLAC, Economic Survey of Latin America and the Caribbean, 2012, Tables A2 and A6, pp. 119-20; and ECLAC, Statistical Annex, 2016, Table A.1 -A.3. ${ }^{\text {a }}$ Corresponds to direct investment in the reporting economy after deduction of outward direct investment by residents of that country. A negative sign means that outward direct investment exceeds inward direct investment in the reporting economy.

In this connection, critics of the role of TNCs in Latin America (and elsewhere) contend that FDI inflows, even in the best of times, rather than increasing the investable resources of the host nation, actually divert resources away from capital formation because, after a few years, they generate substantial reverse flows in the form of remittances of profit and dividends to the parent companies. They also argue that the reported reverse flows are probably a gross underestimate because of the widespread practice of intra-firm transfer pricing by TNCs, i.e., under-voicing of subsidiaries' exports and over-invoicing of their imports of capital goods and technology (see Chang, 2008; Cypher and Dietz, 2004; Plasshaert, 1994; and Montecinos and Cordero, 2010). In their view, in order to assess the net contribution of FDI to the financing of private capital formation, one must subtract from gross (or net) FDI inflows the repatriation of profits and dividends to the parent companies, often residing in the U.S. for many of the countries in question. Support for this contention can be found in the following figures: profit and dividend remittances by Latin America and the Caribbean to the developed 
countries more than doubled between 2004 and 2012, from $\$ 33.6$ billion to $\$ 158$ billion (see ECLAC, 2012, Table 2.2.1.1, p. 97; and ECLAC, 2016, Table A1.1, p. 88). ${ }^{1}$

To put these figures in perspective, in 2004 and 2012, net FDI inflows to the region were respectively $\$ 50.8$ and $\$ 148.5$ billion; that is, reverse outflows in the form of profits and dividends from Latin America and the Caribbean to the developed countries grew from an already high 66 percent of net FDI inflows in 2004 to over 100 percent (106.4 to be exact) in 2012! That is, during the year 2012 the outflow of resources (in the form of profits and dividends) from the region exceeded the inflow in the form of net FDI by practically $\$ 10$ billion. Moreover, from an individual country standpoint, the remittance of profits and dividends in recent years is even more alarming. For example, consider the case of Chile, a country that has been widely praised for its pursuit of market-based, outward-oriented policies and which has over the 2000-2014 period attracted vast amounts of net FDI inflows, particularly in view of its relatively small size. Nevertheless, given its highly liberal policies towards the repatriation of profits, it has also experienced a huge reverse flow of profits and dividends in recent years, rising from $\$ 2.5$ billion in 2000 to $\$ 11.4$ billion in 2005 and a whopping \$18.2 billion in 2011, far surpassing its net inflows of FDI that year which stood at $\$ 9.5$ billion (ECLAC, 2016, p. 97)! In fact, Chile's remittances of profits and dividends during the 2000-2012 period far exceed those of Mexico's, a much larger country which received far more net FDI inflows over the same interval. ${ }^{2}$

In any event, the surge in FDI flows to the countries of Latin America during the 1990-2008 period was due, in part, to "push factors" in the industrialized countries such as relatively low rates of return on investments during the early 1990s (and early 2000s), as well as "pull factors" in Latin America such as the partial reduction of the debt burden via the use of Brady bonds, expanding consumer markets and natural resource endowments, the implementation of credible macroeconomic stabilization policies, and market-based structural reform programs (see Green, 2005; UNCTAD, 2012). The latter include privatization and debt conversion programs, the liberalization of the tradable sector, the removal of overly restrictive FDI legislation concerning the repatriation of profits and prior authorization of investments, as well as eliminating sectoral restrictions such as local content and export requirements (see Agosin, 1995; UNCTAD, 2012).

The adoption of these outward-oriented, market-friendly policies has reassured both foreign and domestic investors in Latin America's commitment to market-based reforms in the medium run. Only time will tell if these reforms are sustainable in the long run from the standpoint of economic development, particularly in the wake of the Great Recession of 2007-09, the sharp drop in commodity prices beginning in 2014, and the emergence of China as a major destination for FDI flows (see Stiglitz, 2003). ${ }^{3}$ In view of this, Latin America will have to redouble its efforts to attract FDI flows in a more selective manner so that it can modernize and develop its economy and reverse what has been until now a very disappointing regional investment and growth performance, particularly when compared to East Asia and China 


\section{Empirical Model and Results}

From an historical standpoint, empirical work on the determinants of FDI flows to Latin America and the Caribbean have been relatively few given the paucity and inconsistency of the data, as well as the economic and institutional heterogeneity present in these countries. However, in recent years, a number of studies focusing on the determinants (and impact) of FDI flows to several countries of the region have arisen as a result of the renewed surge in net flows to these countries beginning in the second half of the 1980s and the availability of reliable and methodologically consistent time series data for a number of countries (see Agosin, 1995; Bloomstrom and Wolff, 1994; Chowdhury and Mavrotas, 2006; DeMello, Jr., 1997; Ramasamy and Yeung, 2004; Ramirez 2005; Ram and Zhang, 2002;Ros, 1994; Zhang, 2001; and Vadlamannati and Tamazian, 2009).

\section{Model.}

Following the lead of Agosin (1995), ECLAC (1998), Ros (1994), and Zhang (2001), this study estimated a foreign direct investment (FDI) function that pools data for nine major Latin American nations: Argentina, Brazil, Chile, Colombia, Costa Rica, Ecuador, Mexico, Peru, and Uruguay over the 1980-2014 period. ${ }^{4}$ The pooled (fixed-effects) model includes the effect of a number of relevant variables whose economic rationale for inclusion is discussed below. The simplest formulation of the pooled (stacked) regression model is given in Equation (1):

$$
(F D I R)_{i t}=f\left[(L G D P)_{i t-i}, \operatorname{REX}_{\text {it-I }}, D_{\text {it-i, }}, G_{\text {it-i, }}, \text { GED }_{\text {it-i }}, \mathrm{CR}_{\mathrm{it}-\mathrm{i}}, \mathrm{EF}_{\mathrm{it}} ; \mathrm{D}_{\mathrm{i}}\right]+\varepsilon_{\mathrm{it}}
$$

where the regressand, FDIR, is the ratio of FDI inflows to real GDP; it includes standard regressors such as the (lagged) log of real GDP [and the period standard deviations (SDGDP)], the real exchange rate (REX) [and the period standard deviation (SDREX)], and the ratio of debt service payments to exports of goods and services (DS). It also incorporates public investment spending as a proportion of GDP (GIR), government expenditures on education as a percentage of GDP (GED) as a proxy for human capital, credit channeled by the banking system to the private sector (CR) as a percentage of GDP, the economic freedom index (EF) generated by the Fraser Institute, and dummy variables $\left(\mathrm{D}_{\mathrm{i}}\right)$ to explain the variation in FDI flows to Latin America during the $1980-2014$ period. ${ }^{5} \varepsilon_{\text {it }}$ is a normally distributed error term.

\section{Economic Rationale}

Latin America's potential market size is proxied by the lagged value of the log of real GDP (LGDP) because foreign investors make their investment decisions based on expectations generated, in part, by what the level of real GDP was in the preceding year. The sign associated with this variable is expected to be positive. (The lagged growth rate of the log of real GDP was also included as an argument to determine whether it is the percentage change in log of real GDP that is the better proxy; see endnote 6.) This variable was also lagged in order to avoid the inherent simultaneity problem that arises when incorporating this variable as a regressor, viz., it is likely that increased FDI inflows enhance private capital formation and economic growth, Thus, this study also addressed the problem directly as follows: The 
potential endogeneity of the log of real GDP variable was purged by prior regression on FDI inflows. The residuals obtained from this regression were then renamed and substituted in place of the raw log of real GDP variable. Finally, the period standard deviation of real GDP, SDGDP is included in the model to capture the impact of GDP volatility on FDI flows to the region. It is hypothesized that, ceteris paribus, this variable will have a negative effect on FDI flows to the region because the more volatile real GDP is, the greater the uncertainty for foreign investors in terms of anticipated internal aggregate demand, volume of sales, and profits.

The real exchange rate is included in the model because it is the most important link between economic policy and international competitiveness and, as explained in Section II, it is expected to have an indeterminate sign in the Latin America case (see Agosin, 1995). ${ }^{6}$ On the one hand, a considerable proportion of FDI flows to Latin America, in recent years, are concentrated in foreign affiliates which have a strong export orientation, such as agriculture, cellulose and paper, telecommunications, and manufacturing. A ceteris paribus real depreciation of the domestic currency (a rise in REX) should increase the profitability of these sectors and, ceteris paribus, induce FDI flows to them. On the other hand, a real depreciation of the domestic currency reduces the (dollar) value of the remittances of profits and dividends back to the parent company, thereby reducing the real rate of return on the parent company $=\mathrm{s}$ initial (dollar) investment. According to this rationale, a ceteris paribus depreciation of the domestic currency should reduce FDI flows to the country. This variable is introduced with a lag because the decision to invest in new plant, machinery, and equipment in a foreign country takes time due to recognition, implementation, and institutional-legal delays.

The standard deviation of the real exchange rate, $\mathrm{SD}(\mathrm{REX})$ is also included (separately) in the model to capture the impact of exchange rate volatility on FDI flows to the region. It is hypothesized that, ceteris paribus, this variable will have a negative effect on FDI flows to the regions because the more volatile REX is, the greater the uncertainty for foreign investors when it comes to the expected costs and profits in both the tradeable and non-tradeable sectors.

The debt service payments- to- exports ratio, was included to measure country risk; viz., the higher the ratio, the greater the probability that a BOP crisis will emerge which may lead to the imposition of restrictions on profit and dividend remittances, thereby depressing FDI flows to the country. Debt-service payments include both amortization (gradual payment of principal) and interest payments on the country's total external public debt. This variable is also designed to capture the influence of external (exogenous) factors on the Latin America economy, such as the increase in the cost of credit and/or demand for the country's exports. It is anticipated to have a negative and statistically significant effect on inward FDI flows.

Public investment as a proportion of GDP is included as regressor because it is hypothesized in the literature that, ceteris paribus, countries with better roads, bridges, and ports are, on average, more attractive to foreign investors as a result of lower production and transportation costs. However, the variable utilized in this study is not "clean" in the sense that it also 
includes investments undertaken by state-owned enterprises (SOEs) in key sectors of the economy such as industry, banking, mining, energy, and agriculture. If these investments are undertaken by heavily subsidized and/or inefficient SOEs, then government investment may directly (and indirectly via competition for scarce funds) "crowd out" both private domestic and foreign investment (see Devarajan and Zou, 1994; and Erden and Holcombe, 2005). Moreover, during the period in question, many of the countries of Latin America pursued draconian IMF-sponsored stabilization and adjustment programs that led to unprecedented across-the-board cuts in public investment in economic and social infrastructure while, at the same time, they liberalized their economies to capital flows, including FDI flows. In view of this, the impact of this variable on net FDI inflows is indeterminate.

The model also includes government expenditures on education as a percentage of GDP as crude proxy for the quality of the country's human capital. It would have been preferable to have used the secondary or tertiary enrollment ratio, but these variables were not available for the entire period for the countries in question. The rationale for including the GED variable is relatively straightforward. It is hypothesized that, ceteris paribus, the higher the level of education in any given country, the more attractive it is to foreign investors both from a cost standpoint (lower unit labor costs) and a demand-side perspective (greater purchasing power and more informed consumers) (see Ramasamy and Yeung, 2004). The credit variable (CR) is expected to have positive impact on FDI flows because, in many Latin American nations, the quantity constraint is binding in terms of financing the construction of new plant, machinery, and equipment. In other words, a greater pool of investible resources should, ceteris paribus, ease the financing constraint of both foreign and domestic investors (see Erden and Holcombe, 2005).

In order to assess whether the countries in question have a legal-institutional framework conducive to business activity, and are thus relatively more attractive to foreign (and domestic) investors, the well-known economic freedom index generated by the Fraser Institute was included in the model. The general idea is that countries with greater economic freedom have a legal-institutional framework that is more conducive to business activity and economic growth than countries that adopt policies that restrict economic freedom. This index is a summary measure of a number components of "economic freedom" such as monetary policy and price stability, the top marginal tax rate, legal structure and property rights, viability of contracts, and the rule of law. The index has a scale that ranges from 1 to 10 , where a score of 10 represents the highest attainable level of economic freedom. ${ }^{7}$ It is anticipated that this variable will have a positive and statistically significant effect on inward FDI flows to the region. It should be noted that all of the countries in this study report indices that range between 2 and 8, with Chile and Costa Rica at the high end and Ecuador and Peru at the low end. Also, in view of the fact that Fraser Institute did not report economic freedom indices on a consistent basis for all of the countries in the sample, particularly the 1980s, I generated the missing values via linear interpolation and linear extrapolation.

Turning to the qualitative variables, dummy variable D1 equals 1 for the economic crises years associated with the onset and aftermath of the debt crisis (1982-83), the negative spillover effects resulting from the Mexican Peso crisis of 1994-1995, and the sharp fall in 
economic activity as a result of the 2008-2009 economic and financial debacle in the U.S. It is expected to have a negative and significant effect on FDI flows to the region because of the uncertainty generated for expected returns from depressed economic activity, financial instability, and political turmoil. Again, these events may induce government officials to adopt a more nationalistic stance and impose restrictions on foreign investors in terms of the sectoral destination of FDI flows and the repatriation of profits and dividends. D2 is set equal to 1 for the 1991-93 and 1996-1999, and 2011-2013 periods (acceleration of foreign investment flows to the region as a result of push factors in the developed nations and the consolidation of market-based, outward-oriented strategies of economic growth and development that the major countries of the region began to implement following the Brady Plan. The model was also estimated with dummy variable D2 multiplied by real GDP. By estimating this variable interactively with real GDP one can assess whether the consolidation of market-oriented reforms had a positive and significant effect on the capacity of market size to affect real FDI flows.

\section{Data}

The data consists of 9 cross-sectional units, denoted $\mathrm{i}=1, \ldots, 9$, observations at each of 35 periods, $\mathrm{t}=1, \ldots, 35$, for a total of 315 observations. Most of the economic data (including foreign direct investment) used in this study were obtained from official sources such as various issues of ECLAC's Statistical Yearbook for Latin America and the Caribbean (Santiago: United Nations), UNCTAD's World Investment Report (Geneva: United Nations), and the World Bank Data (online). The data for public investment refers to fixed capital formation; i.e., it excludes financial investment. According to the International Finance Corporation (IFC), the data has been obtained from the following sources: World Bank Country Economic Memoranda, Public Investment Review, and Public Expenditure Reviews. For further details, see the I.F.C.'s Trends in Private Investment in Developing Countries: Statistics for 1970-2000. Finally, the data for the economic freedom index was obtained from various Annual Reports of the Economic Freedom of the World published by The Fraser Institute.

\section{Results}

The estimated results for the various versions of the basic pooled model given in equation (1) above are displayed in Table 2. The pooled model was estimated via the Seemingly Unrelated Regression (SUR) procedure with white cross-section standard errors and covariances. The rationale for utilizing this procedure resides in the plausible hypothesis that economic events such as the debt crisis and/or the business cycle originating in the OECD countries are likely to affect FDI flows to all Latin American countries to varying degrees, thus generating cross-country correlations among the error terms. The generalized least square (GLS) method was used to correct all reported equations for the likely presence of first order serial correlation. Finally, all reported estimates were generated under the fixed effects assumption, viz., under the assumption that time-invariant differences across countries (e.g., history, culture, etc.) can be captured by differences in the constant term.

Equations (1) - (5) report fixed-effects (SUR) estimates for the basic model both with and 
without the dummy variables and, as can be readily ascertained, all estimates have the anticipated signs, but, in some instances, are not statistically significant. For example, the lagged LGDP variable is highly significant in all specifications, suggesting that a 1 percent increase in real GDP in the current period increases the share of FDI flows to the region in the following period by 2.83 percent, ceteris paribus (see, e.g., eq.1). ${ }^{8}$ The volatility in this variable, as measured by the period standard deviation in GDP, is negative and highly significant (see eq. 5). The lagged credit variable (CR) is positive and significant in all the reported estimations, indicating that an easing of the credit constraint is an important determinant of FDI flows to the region. This is not an altogether surprising result in view of the fact that most of the credit granted by the banking sector in Latin America has traditionally been channeled to large enterprises, including subsidiaries of TNC's operating in key sectors of the countries in question (see Aliber, 1970; and ECLAC, 1998). As anticipated, the education variable has a positive and significant effect in all specifications. For example, the estimate in equation (1) suggests that a one percentage point increase in the current ratio of government expenditures on education to GDP will generate an increase of 0.54 percent in the share of FDI flows to the region during the following year, ceteris paribus.

The negative and significant sign for the public investment variable suggests that increases in this variable, ceteris paribus, tend to crowd out net FDI flows to the region for the period in question. As noted above, this may be due to the fact that we are not able to isolate the effect of increased investment spending on economic infrastructure per se given the level of aggregation of the data. It may also be a "statistical artifact" generated from our inability to effectively control for the deleterious impact of the IMF-sponsored stabilization programs on public investment spending during the 1980s, 1990s and 2000s in several of the countries included in this study.

Turning to the real exchange rate variable, it can be seen that it has a lagged negative but insignificant effect on FDI flows; the lack of significance may be due to the opposing effects (discussed above) that a real depreciation of the currency has on the profitability of export-oriented sectors where FDI flows have been concentrated in recent years. Equations (2) - (5) include the SDREX variable designed to capture the impact of the volatility of REX (uncertainty) on FDI flows to the region and, as expected, it has a negative and significant effect. The debt-service variable also has a lagged negative effect in all reported estimations were it is included, but it is marginally significant in eqs. (1), (2) and (5).

As expected, the economic freedom variable (lagged one period) has a positive and highly significant effect in equation (5) for the period under review without altering the significance or sign of the other quantitative variables. The interpretation of this variable should be undertaken with care given its inherently subjective nature, but the estimate does suggest that a "better" macroeconomic environment and legal-institutional framework is conducive to attracting FDI flows to the region. The dummy variables reported in equations (1) - (5) also have their anticipated and significant effects, and the interaction term reported in equation (4) suggests that the market-based, outward-oriented reforms of the early 1990s and 2000s further enhanced the impact of market size on the share of FDI flows to Latin America by an additional 0.04 percent, ceteris paribus. 
To determine whether the null hypothesis that there are no cross-correlations across countries (the homogeneity assumption) is valid, we utilized the following likelihood ratio test:

$$
\lambda \operatorname{lr}=-2(\operatorname{lnLr}-\ln L u)
$$

This test statistic is asympotically distributed as a chi-squared random variable with $[n(n-1)] / 2$ (36) degrees of freedom, where $n$ denotes the number of cross sections. LnLr refers to the $\log$ likelihood for the constrained model and the $\operatorname{lnLu}$ is the log likelihood for the unconstrained (SUR) model. The critical values at the 1 and 5 percent level are, respectively 50.9 and 43.8. The computed likelihood ratio statistics reported in Table 2 (row $\lambda \mathrm{lr}$ ) are all significant at least at the 5 percent level. These estimates indicate that the null hypothesis of no cross-correlation across the nine countries can be rejected. That is, it is not possible for researchers to assume away the economic impact of regional shocks when estimating pooled investment functions for the region over the past two decades.

\section{Panel Unit Root Tests}

A well established practice in individual time series work is to determine whether the individual variables are non-stationary (exhibit unit roots) and if they are related to one another in a stable long-run (cointegrated) relationship. In recent years, a number of investigators, notably Levin, Lin and Chu (2002), Breitung (2000), Hadri (1999), Pedroni (1999), and Im, Pesaran and Shin (2003) have developed panel-based unit root tests that are similar to tests carried out on a single series. Interestingly, these investigators have shown that panel unit root tests are more powerful (less likely to commit a Type II error) than unit root tests applied to individual series because the time series dimension is enhanced by the number of cross sections (see Baltagi, 2001). Moreover, in contrast to individual unit root tests which have complicated limiting distributions, panel unit root tests have the added benefit that they lead to statistics with a normal distribution in the limit.

With the exception of the IPS, Pedroni, and the ADF Fisher Chi-Square tests, all of the aforementioned tests assume that there is a common (identical) unit root process across the relevant cross-sections. The LLC and Breitung tests employ a null hypothesis of a unit root using the following basic Augmented Dickey Fuller (ADF) specification:

$$
\Delta \mathrm{e}_{\mathrm{it}}=\alpha \mathrm{e}_{\mathrm{it}-1}+\Sigma \beta_{\mathrm{ij}} \Delta \mathrm{e}_{\mathrm{it}-\mathrm{j}}+\mathrm{X}_{\mathrm{it}} \delta+v_{\mathrm{it}}
$$

where $\mathrm{e}_{i t}$ refers to the (stacked) residuals of the SUR regressions in Table 2, X' represents exogenous variables in the model such as country fixed effects and individual time trends, and vit refers to the error terms which are assumed to be mutually independent disturbances. ${ }^{9}$ As indicated above, it is also assumed that $\alpha=\rho-1$ is identical across the nine cross-sections, but the lag order for the difference terms across the nine countries is allowed to vary. By contrast, the less restrictive IPS test (and ADF Fisher Chi-square test reported below) estimates a separate ADF regression for each of the nine cross sections to allow for individual unit root processes; i.e., $\rho_{\mathrm{i}}$ may vary across cross-sections which means that, under the alternative hypothesis, some (but not all) series can still be non-stationary. 


\section{Macrothink}

Business and Economic Research

ISSN 2162-4860

2017, Vol. 7, No. 2

Table 3 below reports (summary) panel unit root tests on the residuals of the five SUR regressions reported in Table 2 above. As can be readily seen, the LLC, Breitung and IPS tests strongly reject the unit root null for all of the equations reported in Table 2 . The table also reports the widely used Hadri-Z test statistic, which, as opposed to the aforementioned tests, uses a null of no unit root. Again, the results of this test are consistent with those of LLC and Breitung because it fails to reject the null in favor of a unit root.

This study also performed a Augmented Dickey Fuller (ADF) Fisher unit root test proposed by Maddala and Wu (1999) to determine whether the residuals of each of the nine cross-sections (countries) exhibit a unit root. In this test, the null hypothesis of a unit root for the residuals of all nine cross sections is set against the alternative hypothesis of some [not all] cross sections without a unit root in the residuals. The p-values reported in Table 4 for each cross section suggest that, with the exception of Brazil, a unit root can be rejected at least at the 5 percent level. Also, the ADF Fisher statistic (143.31) and the Choi Z-stat. (-9.85) for the stacked residuals indicate that the null hypothesis of non-stationarity is strongly rejected.

The finding that the (stacked) residuals, including all but one of the residuals from the individual cross sections, do not contain a unit root suggests that there exists an equilibrium (stable) relationship that keeps the relevant variables in the pooled FDI function in proportion to one another in the long run. This is a highly important finding because often in panel studies researchers incorrectly apply the GLS method to regressions that are nonstationary in nature, thereby generating spurious results (see Baltagi, 2001).

Finally, the recently developed Residual Cointegration Test proposed by Pedroni (1999) was employed. Basically, it generates four panel statistics and three group statistics to test the null hypothesis of no cointegration against the alternative of cointegration. In the case of panel statistics, the first-order autoregressive term is assumed to be the same across all the nine cross sections (the so-called within dimension test), while in the case of group statistics the parameter is allowed to vary over the cross sections (referred to as the between-dimension test). If the null is rejected in the more restrictive panel case, then the variables of the foreign investment function are cointegrated for all the countries. On the other hand, if the null is rejected in the group panel case, then cointegration among the relevant variables exists for at least one of the nine countries.

The statistics presented in Table 5 are distributed, in the limit, as standard normal variables with a left hand rejection region, with the exception of the variance ratio statistic. The reported panel and group statistics for the residuals generated from equation (5) suggest that there is strong evidence of cointegration. The reported statistics for the Augmented Dickey Fuller (ADF)-t and Phillips and Perron (non-parametric)-t tests suggest that the null hypothesis of no cointegration can be rejected at the one percent level of significance.

\section{Summary and Conclusions}

This paper first examined some of the major economic and institutional determinants of FDI flows to Latin America within the OLI framework established by John Dunning. Second, the evidence reported in Section II suggests that net FDI flows to Latin America during the 
decade of the 1990s and 2000s have been substantial, both in relation to GDP and domestic capital formation. Another favorable trend in recent years is the high proportion of FDI flows directed to Greenfield investments, viz., in new enterprises in leading sectors, as opposed to cross-border mergers and acquisitions that were relatively more important during the privatization frenzy that hit the region during the 1990s (see UNCTAD, 2015). However, the evidence also indicates that reverse flows in the form of profits and dividend remittances have continued to grow into the decade of the 2000s both in absolute and relative terms--not to mention unreported transfers. Once these reverse flows deducted from the gross or net FDI inflows, the contribution of FDI to the financing of capital formation, although increasing, is far less than advertised. From the standpoint of long-term economic development, this worrisome trend brings into question overly liberal short-run policies designed to attract FDI flows to the region, such as in the case of Chile where the country eliminated all taxes on repatriated profits and dividends, as well as minimum stay and export requirements during the 1990s (see Edwards, 1999).

Third, the SUR regressions suggest that market size (proxied by lagged real GDP or the lagged growth rate in real GDP) has a positive and statistically significant effect on FDI flows to the region, while its period standard deviation (a volatility proxy) has a negative and statistically significant effect. These results are in line with those of most studies which find that TNCs are attracted to markets that exhibit steady and positive growth. The lagged credit variable and the education variable also have their expected positive and significant effect on FDI flows, while the debt-service ratio and standard deviation of the real exchange rate have their anticipated negative signs and are significant in most regressions, albeit at the marginal level for the debt-service ratio variable. The institutional variables, as captured by the dummy variables and the Fraser Institute's economic freedom variable, have their anticipated effects, with the economic freedom variable having a positive and economically important effect on FDI flows in eq. 5. The only variable with a somewhat unexpected (negative) and significant sign is lagged public investment as a percentage of GDP. As explained in the text, this may be due to a number of factors, ranging from data problems which prevent us from isolating the effect of infrastructure investment spending per se to the unprecedented reduction and variability in the ratio of public investment to GDP in recent years as a result of severe stabilization and adjustment programs in several countries of the region for the period under review.

Fourth, this study performed panel unit root tests on the pooled residuals of the SUR regressions and determined that a non-spurious (cointegrated) relationship exists among the relevant variables. This is a highly important finding because it indicates that the variables of the pooled model have a stable long-term relationship that keeps them in proportion to one another.

From a policy standpoint, the results in this paper are consistent with those of other studies cited above, and they suggest that policies that promote sustained economic growth, investments in education, macroeconomic stability--particularly GDP and exchange rate stability--and a legal-institutional framework conducive to business activity, are likely to attract FDI flows to the region on a long-term basis. 
Table 2. Seemingly Unrelated Regressions (SUR), Dependent variable: FDI $\mathrm{t}_{\mathrm{t}}$ 1980-2014

\begin{tabular}{|c|c|c|c|c|c|}
\hline Variables & (1) & (2) & (3) & (4) & (5) \\
\hline \multirow[t]{2}{*}{ LGDP $_{\mathrm{t}-1}$} & 2.83 & 2.42 & 2.75 & 2.82 & 2.74 \\
\hline & $(2.60)^{* * *}$ & $(3.22)^{* * *}$ & $(3.66)^{* * k}$ & $(3.73)^{* * *}$ & $(3.23)^{* * *}$ \\
\hline \multicolumn{2}{|c|}{$\mathrm{D}_{2} *(\mathrm{LGDP})_{\mathrm{t}-1}$} & $-\cdots$ & $-\cdots$ & 0.04 & $-\cdots$ \\
\hline \multicolumn{6}{|c|}{$(1.90)^{\text {*** }}$} \\
\hline \multirow[t]{2}{*}{$\mathrm{SDLGDP}_{\mathrm{t}-1}$} & $-\cdots$ & $-\cdots \cdot$ & $-\cdots$ & $-\cdots$ & -3.84 \\
\hline & & & & & $(-2.14)^{\text {*kt }}$ \\
\hline \multirow[t]{2}{*}{$\mathrm{CR}_{\mathrm{t}-1}$} & 0.02 & 0.02 & 0.02 & 0.02 & 0.02 \\
\hline & $(2.10)^{* * *}$ & $(2.26)^{* *}$ & $(2.18)^{* * *}$ & $(2.21)^{* * *}$ & $(2.97)^{* * *}$ \\
\hline \multirow[t]{2}{*}{$\mathrm{GIR}_{\mathrm{t}-1}$} & -0.21 & -0.22 & -0.18 & -0.19 & -0.19 \\
\hline & $(-2.61)^{* *}$ & $(-2.98)^{\text {*k }}$ & $(-2.37)^{\text {k*k }}$ & $(-2.47)^{\text {k*k }}$ & $(-2.61)^{\text {*k }}$ \\
\hline \multirow[t]{2}{*}{$\mathrm{GED}_{\mathrm{t}-1}$} & 0.54 & 0.61 & $0 . .86$ & 0.86 & 0.82 \\
\hline & $(2.99)^{* * *}$ & $(3.97)^{* * *}$ & $(5.57)^{* * *}$ & $(5.61)^{* * *}$ & $(5.74)^{* * *}$ \\
\hline \multirow[t]{2}{*}{$\mathrm{DS}_{\mathrm{t}-1}$} & -0.01 & -0.01 & -0.01 & -0.01 & -0.01 \\
\hline & $(-1.40)^{*}$ & $(-1.64)^{*}$ & $(-1.02)$ & $(-1.11)$ & $(-1.71)^{* * *}$ \\
\hline \multirow[t]{2}{*}{$\mathrm{REX}_{\mathrm{t}-1}$} & -0.06 & $\cdots$ & - & $-\cdots$ & $\cdots$ \\
\hline & $(-1.08)$ & & & & \\
\hline \multirow[t]{2}{*}{ SDREX $_{\mathrm{t}-1}$} & $\ldots$ & -0.20 & -0.19 & -0.20 & -0.23 \\
\hline & & $(-1.92)^{* * *}$ & $(-1.67)^{*}$ & $(-1.79)^{\text {*** }}$ & $(-1.74)^{* * *}$ \\
\hline \multirow[t]{2}{*}{$\mathrm{EF}_{\mathrm{t}-1}$} & $-\cdots$ & $-\cdots$ & $-\cdots$ & $-\cdots$ & 0.43 \\
\hline & & & & & $(2.62)^{* * *}$ \\
\hline \multirow[t]{2}{*}{$\mathrm{D}_{1}$} & -0.58 & -0.61 & -0.52 & -0.54 & -0.72 \\
\hline & 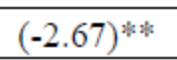 & $(-2.90)^{* * *}$ & $(-2.54)^{\text {k }}$ & $(-2.63)^{* * 3}$ & $(-3.98)^{\text {水水 }}$ \\
\hline \multirow[t]{2}{*}{$\mathrm{D}_{2}$} & -...- & $\ldots$ & 0.51 & $\cdots$ & --- \\
\hline & & & $(2.22)^{* * *}$ & & \\
\hline $\operatorname{Adj}^{2}$ & .80 & .83 & .83 & .83 & .82 \\
\hline$\lambda_{\mathrm{lr}}$ & $61.4^{* * *}$ & $62.4 * *$ & $58.2 * *$ & $63.3^{* * *}$ & $62.1^{*} *$ \\
\hline obs. & 315 & 315 & 315 & 315 & 315 \\
\hline D.W. & 2.02 & 2.03 & 2.02 & 1.99 & 2.01 \\
\hline
\end{tabular}

Note: ** denotes significance at least at the 5 percent level;* denotes significance at the 10 percent level. Eviews 9.5 estimation.

Table 3. Pool Unit Root Tests on Residuals: Individual Effects Estimation, 1980-2014

\begin{tabular}{|lccccc|}
\hline \multicolumn{7}{c|}{ Equations } \\
\hline Method & $(1)$ & $(2)$ & $(3)$ & $(4)$ & $(5)$ \\
\hline LLC & $-7.43^{*}$ & $-5.76^{*}$ & $-6.68^{*}$ & $-6.61^{*}$ & $-6.45^{*}$ \\
\hline Breitung & $-4.33^{*}$ & $-4.33^{*}$ & $-4.29^{*}$ & $-2.54^{*}$ & $-4.29^{*}$ \\
\hline IPS & $-7.09^{*}$ & $-7.27^{*}$ & $-7.44^{*}$ & $-7.23^{*}$ & $-4.72^{*}$ \\
\hline Hadri & 1.31 & 1.31 & 0.78 & 0.99 & 0.64 \\
\hline
\end{tabular}

Note: LLC= Levin, Lin, Chu (2002), IPS= Im, Pesaran, Shin (2003). The statistics are asymptotically distributed as standard normal with a left hand side rejection area, except on the Hadri test, which is right sided. A * indicates the rejection of the null hypothesis of nonstationarity (LLC, Breitung, IPS) or stationarity (Hadri) at least at the 5 percent level of significance. Estimations undertaken with Eviews 9.5 


\section{Macrothink}

Business and Economic Research ISSN 2162-4860 2017, Vol. 7, No. 2

Table 4. ADF Fisher Unit Root Test on Residuals: Individual Effects Estimation, 1980-2014

\begin{tabular}{|lclcc|}
\hline \multicolumn{2}{l}{$\begin{array}{l}\text { Method } \\
\text { ADF Fisher Chi-square }\end{array}$} & $\begin{array}{l}\text { Statistic } \\
143.313\end{array}$ & $\begin{array}{c}\text { Prob } \\
0.000\end{array}$ & \\
\hline ADF Choi Z-stat & & -9.848 & 0.000 & \\
\hline Intermediate ADF Test Results on Residuals & & & Max Lag & Obs. \\
\hline Cross Section & Prob. & Lag & 4 & 20 \\
\hline RESID AR & 0.0002 & 0 & 4 & 20 \\
\hline RESID BA & 0.0774 & 0 & 4 & 20 \\
\hline RESID CH & 0.0000 & 0 & 4 & 19 \\
\hline RESID CO & 0.0000 & 1 & 4 & 20 \\
\hline RESID CR & 0.0004 & 0 & 4 & 20 \\
\hline RESID EC & 0.0014 & 0 & 4 & 20 \\
\hline RESID ME & 0.0001 & 0 & 4 & 20 \\
\hline RESID PE & 0.0001 & 0 & 4 & \\
RESID UR & 0.0169 & 1 & &
\end{tabular}

Note: Probabilities for ADF Fisher tests are computed using an asymptotic Chi-square distribution. Automatic selection of lags based on Schwartz Information Criterion: 0-1. Total number of observations: 180. Estimations performed by Eviews 9.5 .

Table 5. Pedroni Residual Cointegration Test, 1980-2014. Null Hypothesis: No cointegration

\begin{tabular}{|lcc|}
\hline & Alternate Hypothesis: common AR coefs. (within-dimension). \\
\hline & Statistic & Probability \\
\hline Panel rho-statistic & -2.142 & 0.016 \\
\hline Panel PP-statistic & -15.306 & 0.000 \\
\hline Panel ADF-statistic & $\mathbf{- 5 . 4 3 1}$ & 0.000 \\
\hline & Alternative Hypothesis: individual AR coefs. (between-dimension) \\
\hline & Statistic & Probability \\
\hline Group rho-statistic & -1.301 & 0.097 \\
\hline Group PP-statistic & -18.819 & 0.000 \\
\hline Group ADF-statistic & -6.094 & 0.000 \\
\hline
\end{tabular}

Total number of observations: $315(35 * 9)$. Lag selection: SIC with a maximum lag of 3. Estimations performed by Eviews9.5

\section{References}

Agosin, M. R. (ed.) (1995). Foreign Direct Investment in Latin America, Inter-American Development Bank, USA.

Aliber, R. (1970). A Theory of Direct Foreign Investment, in Kindleberger. C.P. (ed.) The International Corporation: A Symposium. Cambridge, MA: MIT Press.

Baltagi, B. H. (2001). Econometric Analysis of Panel Data, $2^{\text {nd }}$ edition, John Wiley \& Sons, LTD., USA.

Bird, G., \& Rajan, R. S. (2001). International Currency Taxation and Currency Stabilization 
Developing Countries, The Journal of Development Studies, 37, 21-38.

https://doi.org/10.1080/00220380412331321951

Bloomstrom, M., \& Wolff, E. (1994). Multinational Corporations and Productivity Convergence in Mexico, in Baumol, W., Nelson, R. and Wolff, E. (eds.) Convergence of Productivity: Cross-National Studies and Historical Evidence. Oxford: Oxford University Press.

Bosworth, B. P., \& Collins, S. M. (1999). Capital Flows to Developing Economies: Implications for Savings and Investment, Brookings Papers on Economic Activity, 1, 143-80. https://doi.org/10.2307/2534664

Breitung, J. (2000). The Local Power of Some Unit Root Tests for Panel Data, in Baltagi, B. (ed.) Advances in Econometrics, Vol. 15: Non-stationary Panels, Panel Cointegration, and Dynamic Panels. Amsterdam: JAI Press, 161-178.

https://doi.org/10.1016/S0731-9053(00)15006-6

Chang, H. J. (2008). Bad Samaritans. Bloomsbury Press, USA.

Chowdhury, Abdur \& Mavrotas, George. (2006). FDI and Growth: What Causes What? World Economy, 29(1), 9-19. https://doi.org/10.1111/j.1467-9701.2006.00755.x

Cypher, J. M., \& Dietz, J. L. (2004). The Process of Economic Development, Routledge, USA.

De Mello, L. R. Jr. (1997). Foreign Direct Investment in Developing Countries and Growth: A Selective Survey, Journal of Development Studies, 34, 1-34.

https://doi.org/10.1080/00220389708422501

Dunning, J. H. (1981). International Production and the Multinational Enterprise, Allen \& Unwin, Publishers USA

Dunning, J. H. (1988). Explaining International Production, London: Harper \& Collins.

Economic Commission for Latin America and the Caribbean (ECLAC). (2008). Preliminary Overview of the Economies of Latin America and the Caribbean, Santiago, Chile: United Nations.

ECLAC. (2006). Foreign Investment in Latin America and the Caribbean, 2005 Report, Santiago, Chile: United Nations.

ECLAC. (2011). Economic Survey of Latin America and the Caribbean 2009-2010, Santiago, Chile: United Nations.

ECLAC. (2012). Economic Survey of Latin America and the Caribbean 2010-2011, Santiago, Chile: United Nations.

ECLAC. (2016). Economic Survey of Latin America and the Caribbean 2014-2015, Santiago, Chile: United Nations.

Edwards, S. (1999). How Effective are Capital Controls? Journal of Economic Perspectives, 
13, 65-84. https://doi.org/10.1257/jep.13.4.65

Erden, L., \& Holcombe, R. G. (2005). The Effects of Public Investment on Private Investment in Developing Economies. Public Finance Review, 33, 575-602.

https://doi.org/10.1177/1091142105277627

Everhart, S. S., \& Sumlinski, M. A. (2001). Trends in Private Investment in Developing Countries: Statistics for 1970-2000, International Finance Corporation, 44, The World Bank, USA.

Figueroa, A. (1998). Equity, Foreign Investment and International Competitiveness in Latin America, The Quarterly Review of Economics and Finance, 38, 391-408.

https://doi.org/10.1016/S1062-9769(99)80124-0

Glen, J. D., \& Sumlinski, M. A. (1996). Trends in Private Investment in Developing Countries, International Finance Corporation, The World Bank, USA.

Hadri, K. (1999). Testing the Null Hypothesis of Stationarity Against the Alternative of a Unit Root in Panel Data with Serially Correlated Errors, Manuscript, Department of Economics and Accounting, University of Liverpool.

Inter-American Development Bank (IDB). (1999). Facing Up to Inequality in Latin America, Economic and Social Progress in Latin America, 1998-1999 Report, Inter-American Development Bank, USA.

Inter-American Development Bank (IDB). (2006). The Emergence of China: Opportunities and Challenges for Latin America and the Caribbean, Inter-American Development Bank, USA.

Im, K. S., Pesaran, M. H., \& Shin, Y. (2003). Testing for Unit Roots in Heterogeneous Panels, Journal of Econometrics, 115, 53-74. https://doi.org/10.1016/S0304-4076(03)00092-7

Kumar, A. (2007). Does Foreign Direct Investment Help Emerging Economies? Economic Letter, 2, 1-8.

Levi, M. D. (2005). International Finance, $4^{\text {th }}$ ed., Routledge, USA.

Levin, A., Lin, C. F., \& Chu, C. (2002). Unit Root Tests in Panel Data: Asymptotic and Finite-Sample Properties, Journal of Econometrics, 108, 1-24.

https://doi.org/10.1016/S0304-4076(01)00098-7

Maddala, G. S., \& Wu, S. (1999). A Comparative Study of Unit Root Tests with Panel Data and A New Simple Test, Oxford Bulletin of Economics and Statistics, 61, 631-52.

https://doi.org/10.1111/1468-0084.61.s1.13

Miller, R. R., \& Sumlinski, M. A. (1994). Trends in Private Investment in Developing Countries, Working Paper No. 20, International Finance Corporation, World Bank, USA.

Montecinos, Juan, A., \& Jose A. Cordero (2010). Capital Controls and Monetary Policy in Developing Countries, Center for Economic and Policy Research, Washington, D.C., April, 
$1-33$.

Mortimore, M. (2003). The Impact of TNC Strategies on Development in Latin America and the Caribbean, Published for Overseas Development Institute (UK), 1-23.

North, D. C. (1990). Institutions, Institutional Change and Economic Performance, Cambridge University Press, USA. https://doi.org/10.1017/CBO9780511808678

Pedroni, P. (1999). Critical Values for Cointegration Tests in Heterogeneous Panels with Multiple Regressors, Working Paper, Indiana University, July 25, 1999, 1-19. Subsequently published in Oxford Bulletin of Economics and Statistics, 61, Special Issue.

Plasshaert, S. (ed.). (1994). Transnational Corporations: Transfer Pricing and Taxation, London: Routledge.

Ram, R., \& Zhang, K. H. (2002). Foreign Direct Investment and Economic Growth: Evidence from Cross-Country Data for the 1990s, Economic Development and Cultural Change, 51, 205-215. https://doi.org/10.1086/345453

Ramasamy, B., \& Yeung, M. (2004). The European Union's Foreign Direct Investment into Indonesia: Determinants and Threats, in Kehal, H.S., Foreign Direct Investment in Developing Countries, Palgrave Macmillan, Ltd., USA, 134-153.

https://doi.org/10.1057/9780230554412_8

Ramirez, M. D. (2000). Foreign Direct Investment in Mexico: A Cointegration Analysis, Journal of Development Studies, 37, 138-162. https://doi.org/10.1080/713600062

Ramirez, M. D. (2005). Did Institutional Factors Enhance FDI Flows to Chile During the 1985-2001 Period? A Cointegration Analysis, Journal of Emerging Markets, 10, 18-29.

Ros J. (1994). Financial Markets and Capital Flows in Mexico, in Ocampo, J.A. and Steiner, R. (eds) Foreign Capital in Latin America, Inter-American Development Bank, USA.

Spitaler, E. (1971). A Survey of Recent Quantitative Studies of Long-Term Capital Movements, IMF Staff Papers, 31, 189-217.

Stiglitz, J. E. (2003). Whither Reform? Towards a New Agenda for Latin America, Cepal Review, 80, 7-38.

UNCTAD. (1999). World Investment Report 1999, New York: United Nations Conference on Trade and Development.

UNCTAD. (2005). World Investment Report 2005, New York: United Nations Conference on Trade and Development.

UNCTAD. (2012). World Investment Report 2012, New York: United Nations Conference on Trade and Development.

UNCTAD. (2015). World Investment Report 2015, New York: United Nations Conference on Trade and Development. 
Vadlamannati, K., \& Tamazian, A. (2009). Growth Effects of Foreign Direct Investment and Economic Policy Reforms in Latin America, MPRA Paper No. 14133

World Bank. (1994). World Development Report 1994: Infrastructure for Development, Oxford University Press, USA.

Yeager, T, J. (1999). Institutions, Transition Economies, and Economic Development, Westview Press, USA.

Zhang, Kevin, H. (2001). Does FDI Promote Economic Growth? Evidence from East Asia and Latin America, Contemporary Economic Policy, 19, 175-185.

https://doi.org/10.1111/j.1465-7287.2001.tb00059.x

${ }^{1}$ Between 1990 and 2000, FDI inward stock in Latin America (1990 dollars) almost tripled (2.93 times) from $\$ 175.6$ billion to $\$ 507.4$ billion. More recent data reported by UNCTAD indicates that the surge has continued into the 2000s, with the stock of FDI quadrupling to $\$ 2.048 .1$ billion in 2011! (UNCTAD, 2012, Table I.2, p. 175). In relative terms, FDI stock as a percentage of GDP rose from 10.1 percent in 1990 to 25 percent in 2001 (see UNCTAD, 2005, Table B.3; and ECLAC, 2002.) The remarkable increase in FDI inward stock during the 1990s is far greater than that of the entire "lost decade" of the 1980s. By comparison, China's FDI inward stock (1990 dollars) was less than half of Latin America's at an estimated \$193.4 billion in 2001, and although it rose sharply to an estimated $\$ 245.5$ billion in 2004, it was still far below that of Latin America which stood at an impressive \$723.8 billion (UNCTAD, 2005, Table B.2).

${ }^{2}$ ECLAC (2016) reports that profit remittances on FDI for Mexico averaged $\$ 9$ billion for the 2000-2012 period, while those for Chile averaged $\$ 13.5$ billion, or one and a half times as much. In fact, there were five years (2006-2008, and 2010-12) when profit remittances on FDI for Chile approximated or exceeded $\$ 20$ billion, while in the case of Mexico, for the same years (2006-2008, and 2011-12), they ranged between $\$ 10$ and $\$ 14$ billion. Needless to say, these outflows are not only large in absolute terms but relative to GDP and GFCF as well.

${ }^{3}$ Data for 2005 suggest that FDI inflows to China are estimated at US\$72.4 billion which, if confirmed, would fall slightly below the total inflows to Latin America and the Caribbean as a whole at an estimated US\$75.5 billion. In fact, China's share of total worldwide FDI flows in 2005 was estimated at 7.7 percent, which would mean that China was the third largest recipient of FDI in the World, behind the United States and the United Kingdom (see UNCTAD, 2007).

${ }^{4}$ Data for the variables in question were obtained from various issues of ECLAC and the World Data Bank (World Development Indicators). The period had to be shortened because several years of data were missing for variables such as public investment spending as a percentage of GDP, public spending on education as a percentage of GDP, and credit provided by the banking sector to private sector as a percentage of GDP. 
${ }^{5}$ See Agosin (1995, pp. 121-122) who reports estimates for a simple regression model that tries to explain the variation in FDI flows to Chile during the 1975-93 period. He finds that both the level of real GDP in constant dollars and the real depreciation of the exchange have a positive and statistically significant effect on FDI flows. He also includes a dummy variable to capture the adoption of the debt conversion program (Chapter XIX), and finds that it also has a positive and statistically significant impact on FDI flows. The major problem with this otherwise interesting and thought-provoking paper is that the author does not undertake a unit root and cointegration analysis of the FDI investment relationship.

${ }^{6}$ It would be preferable to use a more direct measure of costs such as unitary labor costs.

Unfortunately, data on unit labor costs for the period under review is not available for all the countries in the sample in a consistent and reliable form.

${ }^{7}$ It is important not to confuse economic freedom with political and civil liberties. Countries may confer upon their citizens a substantial amount of political and civil liberty in the form of fair and competitive elections and freedom of the press, but still pursue policies that are inimical to economic freedom such as high levels of taxation and excessive government intervention and regulation.

${ }^{8}$ The regressions with the unpurged log of real GDP variable were similar to those reported in Table 2, but the magnitude of the estimated coefficients for the "raw" LGDP variables were significantly higher. The model was also estimated with the lagged growth rate in real GDP and the estimates are reported below:

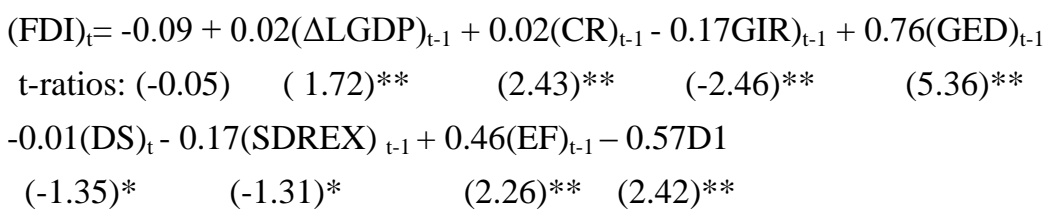

Adj R2=0.83, D.W. $=2.04$, F stat $=83.91$

As can be readily seen, the one-period lag growth rate is highly significant and its inclusion does not alter the significance nor the sign of the other variables. The lag structure was determined via the Akaike- Schwartz information criteria.

${ }^{9}$ The rationale for testing whether the residuals of the SUR regressions exhibit a unit root stems from the finding that panel unit root tests on the included variables (available upon request) revealed that the credit, GDP, debt service, and education variables exhibited a unit root (non-stationarity) in level form.

\section{Copyright Disclaimer}

Copyright for this article is retained by the author(s), with first publication rights granted to the journal.

This is an open-access article distributed under the terms and conditions of the Creative Commons Attribution license (http://creativecommons.org/licenses/by/3.0/). 